\title{
Crisis Management in Tourism - A Literature Based Approach on the Proactive Prediction of a Crisis and the Implementation of Prevention Measures
}

\author{
By Hanno Michail Martens* \\ Kim Feldesz \\ Patrick Merten ${ }^{+}$
}

Increasingly, crisis situations are affecting the globalized tourism industry. Especially, unfavorable news about the political, economic or social situation at a destination are distributed all over the world through numerous media channels. This paper is aimed at providing a literature-based overview on how a decline in visitor numbers due to the influence of a political crisis can be avoided through proactive crisis management. Generally, the key to success is creating a problem-solving action plan including prevention measures that combine all stakeholders' interests and activities. However, in the tourism industry one problem is, that the equal integration of all stakeholders is mostly complicated. The paper provides a literature-based theoretical foundation about crisis management in general and the application of crisis management within tourism. Based upon this foundation an overview of the different stages of crisis management is developed, integrating all stakeholders and influential interest groups.

Keywords: Tourism, Crisis Management, Stakeholder Approach, Proactive Crisis Management

\section{Introduction}

"The significance of a crisis is that one unlucky incident can destroy the good image of a company which has been built up by years of Public Relations work" (Mathes, Gärtner and Czaplicki, 1991). Nowadays, criminal activities and threats from instable situations are continuously influencing the daily life. Especially in tourism their relevance is increasing significantly (Glaesser, 2003). The tourism industry, like no other industry, depends on the creation of favorable images in order to sell their products. It cannot be seen or touched before purchasing it (Salazar and Graburn, 2014). Consequently, the only way for a potential tourist to assess the quality of a tourism product is to rely on the image that he has about it. Crisis situations can negatively impact this image of a tourism destination (Sausmarez, 2007).

In order to analyze, how crises affect the tourism market at a destination and how tourism managers should react to this, a theoretical basis consisting of

\footnotetext{
* Lecturer, Cologne Business School, Germany.

* Research Assistant, Cologne Business School, Germany.

${ }^{\dagger}$ Professor, Cologne Business School, Germany.
} 
a classification of the term crisis, an analysis of crisis management in general and the application of crisis management within tourism, are provided. Although crises can not be stopped by the tourism industry, the stakeholders of the affected tourism destination can make sure the political crisis does not become a tourism crisis. And if it does they can minimize its effects. Therefore, a literature-based approach on how the stakeholders of a destination can actively counter the negative effects of a political crisis is presented. Finally, an overview of the different stages of crisis management is given, presenting responsibilities of the different stakeholders in each stage.

\section{Crisis Management}

Before breaking down the details of crisis management, the term crisis has to be classified according to temporal aspects and to the nature of the crisis. According to Sausmarez (2007) crises can be ranged in three time periods: Potential crises are threats that might occur in the future. They are neither ascertainable, nor are they already existent. Nevertheless, they have to be identified and considered in order to be able to prepare accordingly for the case of an imaginary crisis becoming reality. A latent crisis on the other hand is already occurring. It is a critical situation that is existent, but does not yet have a measurable negative influence. Once a critical situation has turned into an acute crisis, its destructive effect can be clearly perceived and measured. Ritchie (2004) differentiates the speed of crises developing. Immediate crises do not allow for organizations to prepare. Emerging crises develop slower, can be predicted and measures can be taken by involved organizations.

Figure 1. The Temporal Classification of Crises

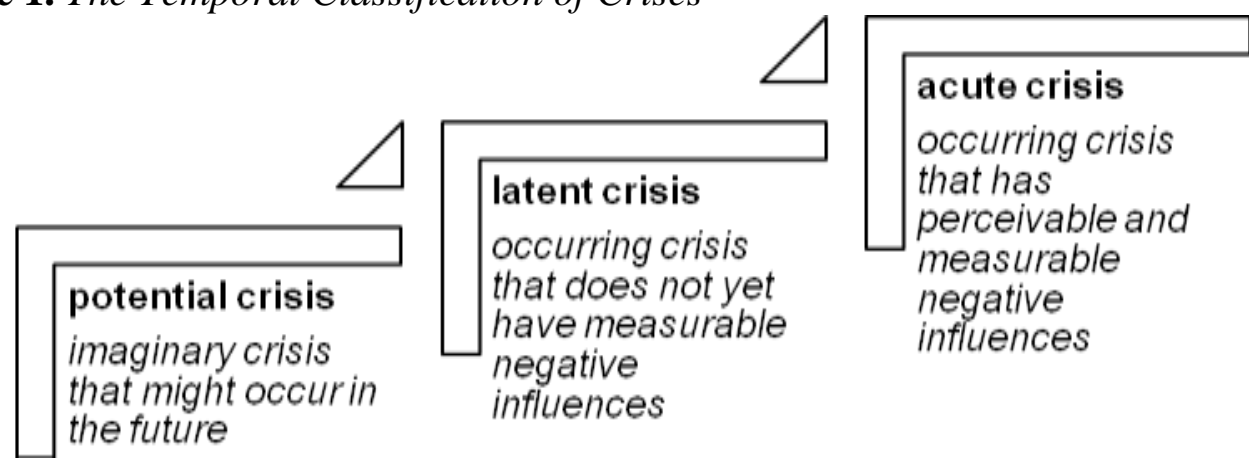

Source: Own illustration based on Sausmarez, 2007

Furthermore, crises can be classified according to their nature. Natural crises are those that are attributable to natural disasters or other unpredictable, natural events. On the contrary, human-induced crises are catastrophic events caused by human beings. Since the cause of a human-induced crisis can in contrary to natural crises not be blamed on inevitable events, this second type 
of crises creates a significantly higher loss of image and loss of faith than natural catastrophes (Glaesser, 2003, Sausmarez, 2007a and Gundel, 2005). Laws and Prideaux (2005) additionally proposed the local division of crisis management: On a regional level, a crisis has effects on the region itself and potentially also on the nation. On the national level, its effects are significant for the tourism industry. Finally, on the global level, a crisis can have a significant impact on tourism flows. As tourists seek for substitute locations whenever they perceive a destination as not being safe, local crises can have an impact on the global tourism industry. Hence, the local division of crises is not further considered for the purpose of this paper.

Crisis management in general can be described as "measures of all types which allow a business to cope with a suddenly occurring danger or risk situation in order to return as quickly as possible to normal business routine" (Scherler, 1996). Like the types of crises themselves, crisis management can also be classified according to its function as well as temporal aspects. Firstly, crisis management can be seen as an institution or as a function. Crisis management institutions are organizations or action groups within organizations, who are responsible for developing strategies for potential crisis management. In general, all stakeholders involved in the tourism product are responsible for crisis management in order to reduce the negative effects of a crisis. As a function, crisis management describes the actual implementation of an action plan as well the adaption of existing tasks and business processes in the case of an acute crisis (Glaesser, 2003).

Secondly, the temporal occurrence of crisis management can be either active or reactive. Active crisis management is describing the proactive prediction of a future catastrophe, the development and implementation of prevention measures and the preparation of an action plan for accurate action steps in case of a crisis. Therefore, active crisis management concentrates on potential crises (Waller, Lei and Pratten, 2014). Moreover, active crisis management can have a greater effect on emerging crises than on immediate crises because the negative impacts are not so dominant yet, research on potential measures can be conducted and actors have the time to implement such measures (Ritchie, 2004). It can be further divided into crisis precautions and crisis avoidance. Firstly, the precaution measures have to be planned and implemented. Secondly, measuring negative effects in an early stage of the crisis and adjusting the action plan accordingly might avoid a potential crisis in the case of a threatening situation (Glaesser, 2003).

Reactive crisis management on the other hand concentrates on already occurring, latent or acute crises. It is defined through coping with negative influences that a crisis has already had and that have already been identified by employing appropriate crisis management instruments (Waller, Lei and Pratten, 2014). Breaking reactive crisis management further down, it can either be offensive or defensive. Once a crisis has occurred, institutions and action groups have to decide, whether they aim at implementing their measures at an early stage of the crisis or whether they await the development of the crisis before they become active. Handling a crisis offensively has the advantage, 
that the possibility of eliminating the cause of the crisis and minimizing negative effects is high. Nevertheless, an accurate preparation is crucial for the success of an offensive strategy. Adopting a defensive crisis management strategy can be reasonable in situations, where it is likely that the early implementation of measures might intensify the situation. Nevertheless, this approach is likely to decrease trustfulness and credibility of the crisis management institutions, since they give up their role as the leading information provider (Glaesser, 2003). Figure 2 summarizes the previously mentioned classifications.

Figure 2. The Temporal Classification of Crisis Management

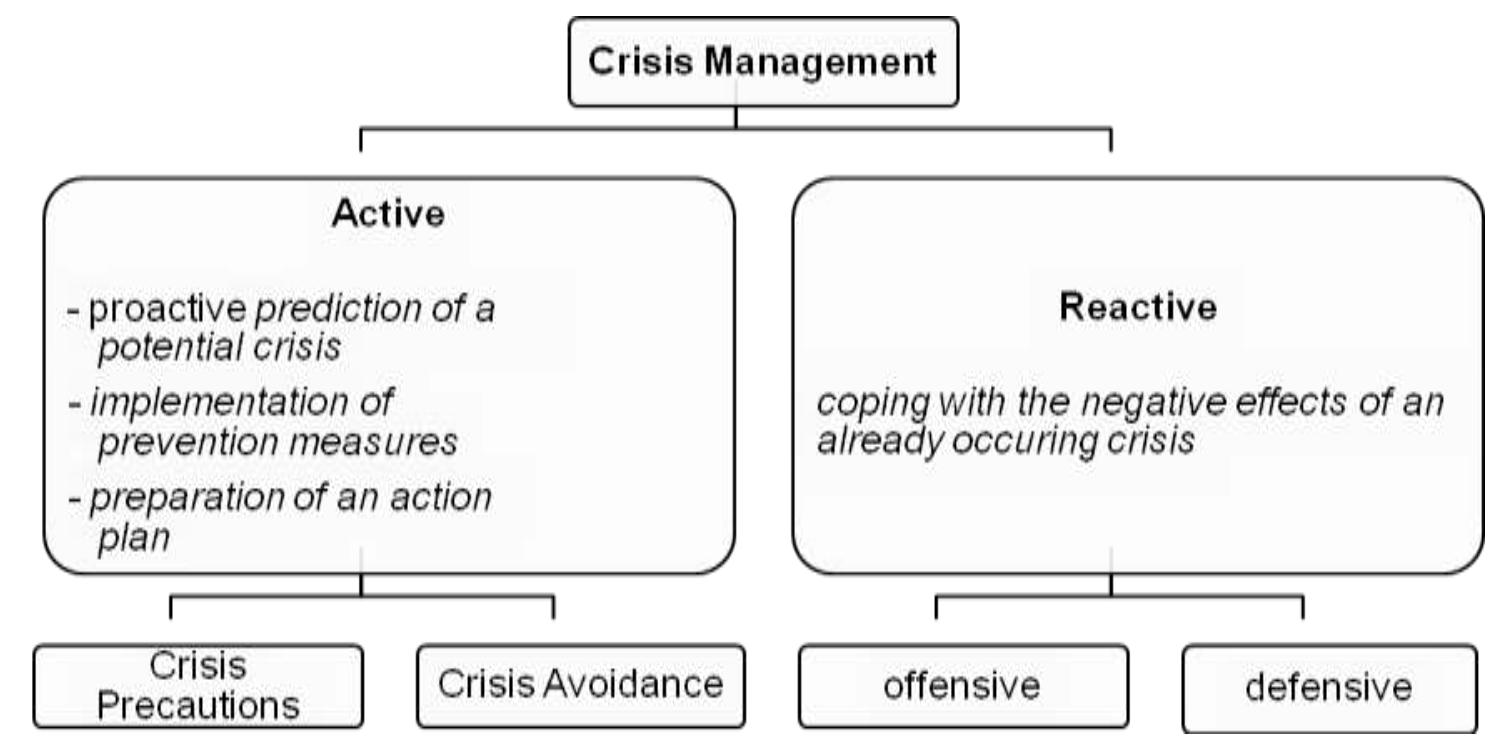

Source: Own illustration based on Waller, Lei and Pratten, 2014, Glaesser, 2003

\section{The Importance of Crisis Management for the Tourism Industry}

What is highly influencing the decision about whether or not to visit a specific tourism destination is its image. The destination image is an abstract picture that potential visitors have in their mind. Every individual has a different image of a certain destination, depending on their previous knowledge based upon facts and figures as well as assumptions and feelings towards the destination. This knowledge and general feeling towards the destination is not necessarily exclusively built upon tourism-related aspects, but also upon the political system and the relationship of the nation with other countries (Kesić and Pavlić, 2011). The destination image differs from other image types since it is inevitably linked to the destinations national image. Image studies relating to other industries are mainly making use of commercial information sources. In contrast the tourism destination image is also highly influenced through nontourism related information sources (Echtner and Ritchie, 2003). 
Hence, news and media are one important information source influencing the destination image, since they inform the public about present political, economic and social events, which have an influence on the destination (Glaesser, 2003). Especially in crisis situations unfavorable images about the political, economic or social situation at a destination are distributed all over the world through numerous media channels (Glaesser, 2003, Kesić and Pavlić, 2011). Consequently, even people, who do not fear threats from political and social instabilities at a specific location, will receive negative news and will be affected by this negative publicity. By getting the impression, that the destination is not safe to visit, potential tourists will exclude the destination from their list of places considered for a visit (Glaesser, 2003).

Without doubt, the safety aspect is of remarkable importance when it comes to tourism destination image and the decision-making process about whether or not to visit a location. The tourism product is mostly intangible and cannot be inspected or tested before purchasing it (Salazar and Graburn, 2014). Besides that, it is also diverse and complex, consisting of a combination of numerous different service providers and organizations. The distance between the location, where the product is purchased and the location, where the service actually is provided, as well as the complexity of its composition makes it difficult for potential tourists to assess the quality of the purchased tourism product in advance (Glaesser, 2003). Hence, marketing a tourism destination highly depends on the creation of favorable images (Salazar and Graburn, 2014). As the impression of the safety at a destination is a crucial decision making factor (Raina, Zhao and Gupta, 2010), tourism providers have to reduce their customers' uncertainty and risk perception (Glaesser, 2003).

\section{Methodology}

There are several types of political crises. Kanlayamasukho (2015) mentions war, coups, terrorism, strikes, riots and political unrest as political crises. As every crisis situation is individual in many ways it requires different approaches by different stakeholders during different stages of the crisis. So far tourism literature provides many individual strategic approaches and many case studies to crisis management. However, every paper has a specific background for special types of crises or disasters. Conflating these approaches, this paper provides an overview of recommendations for action provided in the assessed literature for political crises.

For the purpose of the theoretical approach of this paper 26 academic publications directly related to the issue of effective crisis management in tourism have been reviewed. Hereby four steps were undertaken: Firstly, categories to sort approaches and recommendations were developed out of the literature. Secondly, the recommendations for action specified for individual stakeholders were identified in every paper. Thirdly, these recommendations were assigned to the categories in table 2 . Fourthly, every recommendation was compared to similar suggestions and to suggestions in the same category. 
Finally, out of the 26 studies, 19 studies were used for the overview of stakeholder approaches to crisis management.

\section{Strategic Approaches for Crisis Management in the Tourism Industry}

To provide an overview of the chosen literature the used publications are listed in table 2 . The focus of every paper demonstrates the diversity of crisis management literature in the tourism field. It is identified which aspects are generally seen as important in tourism crisis management throughout the literature. Based on these general findings a more detailed list of recommendations for actions for individual stakeholders is developed.

Table 2. Overview of Literature on Crisis Management in Tourism

\begin{tabular}{|l|l|}
\hline Academic Publication & Focus \\
\hline Araña and León, 2008 & Short-term impacts of a crisis \\
\hline Blake and Sinclair, 2003 & Role of the government in crisis management \\
\hline Durocher, 1994 & Importance of equal stakeholder integration \\
\hline $\begin{array}{l}\text { Ghaderi, Mat Som and Wang, } \\
2014\end{array}$ & $\begin{array}{l}\text { Relevance of knowledge and organizational } \\
\text { learning }\end{array}$ \\
\hline Glaesser, 2003 & Holistic approach for crisis management in tourism \\
\hline Gundel, 2005 & Classification of different types of crises \\
\hline Hass, 2009 & Importance of media and communication \\
\hline Hayes and Patton, 2001 & Significance of pro-active crisis management \\
\hline Hystad and Keller, 2008 & Distinction into three stages of crisis management \\
\hline Joras et al., 2011 & $\begin{array}{l}\text { Importance of equal stakeholder integration and } \\
\text { knowledge distribution }\end{array}$ \\
\hline Keown-McMullan, 1997 & Importance of media and communication \\
\hline Laws and Prideaux, 2005 & $\begin{array}{l}\text { Overview of literature about crisis management in } \\
\text { tourism }\end{array}$ \\
\hline Mair, Ritchie and Walters, 2016 & Focus on post-crisis recovery \\
\hline $\begin{array}{l}\text { Mathes, Gärtner and Czaplicki, } \\
\text { 1993 }\end{array}$ & $\begin{array}{l}\text { Emphasis on the importance of effective } \\
\text { communication }\end{array}$ \\
\hline Neumayer, 2004 & Focus on the impact of political crises \\
\hline Reisinger and Mayondo, 2005 & Impact of a crisis on tourist's risk perception \\
\hline Ritchie, 2004 & Distinction into seven stages of crisis management \\
\hline Sausmarez, 2007a & Focus on post-crisis recovery \\
\hline Sausmarez, 2007b & Focus on post-crisis recovery \\
\hline Sausmarez, 2013 & Distinction into three stages of crisis management \\
\hline Scherler, 1996 & $\begin{array}{l}\text { Emphasis on the importance of effective } \\
\text { communication }\end{array}$ \\
\hline Scott, Laws and Prideaux, 2008 & $\begin{array}{l}\text { Literature review on crisis management in } \\
\text { tourism }\end{array}$ \\
\hline Sönmez and Graefe, 1998 & Impact of a crisis on tourist's risk perception \\
\hline Waller, Lei and Pratten, 2014 & Importance of communication and task assignment \\
\hline $\begin{array}{l}\text { Wintersteiner and Wohlmuther, } \\
\text { 2014 }\end{array}$ & $\begin{array}{l}\text { The role of tourists in crisis management and } \\
\text { peace promotion }\end{array}$ \\
\hline Xu and Grunewald, 2009 & Distinction into three stages of crisis management \\
\hline & \\
\hline
\end{tabular}


Araña and León (2008) focused their study on the short-term impacts of a crisis. As a business case they analyzed the 9/11 terrorist attack in the United States. They found, that previous research primarily focused on the long-term effects on tourism demand in the region affected by the crisis, but not on immediate micro-effects of the terror events on the tourists themselves. As tourists prefer to travel to safe and tranquil destinations their main goal is to minimize the risk of becoming a victim of a terrorist attacks (Neumayer, 2004, Reisinger and Mayondo, 2005).

Sönmez and Graefe (1998) explored the relationship between the destination choice process and terrorism risks. They found out, that there are significant similarities between the definitions of tourism and terrorism. Terrorism is defined as crossing international borders, targeting citizens of many nations and making use of international travel and communication technologies (Schlagheck, 1988). A slightly modified version of this definition could also be applied to the concept of international tourism (Sönmez and Graefe, 1998).

What was widely recognized among the reviewed literature is the division of crisis and disaster management into three phases: pre-crisis, crisis and postcrisis (Hystad and Keller, 2008, Sausmarez, 2013). This separation is also used in the stakeholder approach in table 1. Hystad and Keller (2008) conducted a long-term study on the effects of a forest fire disaster on the tourism industry. Based on this study they developed a model for crisis management. They identified a media management and marketing strategy, communication and coordination with emergency organizations and tourism businesses as the most important tasks previous and during a disaster.

According to $\mathrm{Xu}$ and Grunewald (2009) crisis management can be organized in three steps. The first step is disaster prevention and planning. The proactive crisis management contains the development of coping strategies. Furthermore, an awareness strategy is developed to generate cognition of the vulnerability and capability for all parties involved. In the second step, strategic implementation and resolution, the key point is an effective stakeholder collaboration. Each stakeholder needs to be made fully aware of its role under critical circumstances, so that effective coping strategies and resource management approaches can be put into practice. Thirdly, evaluation and feedback on the current crisis are used to be able to prepare for further crises. Furthermore, re-investments have to be managed to create more resilient surroundings and to boost the confidence in the affected region.

Hayes and Patton (2001) developed an approach for the design and implementation of proactive crisis-management strategies. Their strategic approach includes four steps: Strategic dimensions, risk assessment, crisis management organization and operations and crisis resolution and recovery. The key elements of their approach are the identification and evaluation of risks, approaches for appropriate action in disaster situations and effective communication strategies. 
In 2004, Ritchie, outlined a strategic and holistic approach to crisis management in the tourism industry, from pre-crisis planning through strategic implementation and finally evaluation and feedback. In contrast to Hayes and Patton, Ritchie identified seven stages of crisis management: prevention and planning, strategic implementation, evaluation and control, crisis communication and control, resource management, stakeholder collaboration and resolution, evaluation and feedback. A detailed communication strategy is of great importance, because the media plays an important role in crisis management. Media organizations are in need of accurate and fast information flows (Keown-McMullan, 1997).

Ghaderi, Mat Som and Wang (2014) introduced one further fundamental success factor for effective crisis management. In their study they outlined the importance of knowledge and organizational learning. Starting with knowledge acquisition, tourism organizations constantly need to scan their environment and collect as much information as possible. This information is then shared within the organization in order to diffuse the knowledge among all parties involved. Once all business entities are informed, the knowledge can be applied to tackle the negative impacts of the crisis.

In general, most strategic approaches highlight the following four aspects. Firstly, the importance of an integrated stakeholder approach with reference to the diverse tourism sector with many influential actors is recognized. Secondly, authors mention the need for fast and clear communication, coordination and cooperation. This is especially challenging because of the variety of stakeholders. Thirdly, the importance of the media is emphasized. Fourthly, after the crisis feedback shall be collected and used to improve the preparation for following crises.

\section{Stakeholder Approach for Crisis Management in Tourism}

According to Durocher (1994) the involvement of the public and private sector and full cooperation is essential for a complete recovery. Based on a review of literature on crisis management in tourism, a list of threats, potentials and required actions for proactive crisis management are outlined. The target of table 2 is to create an overview of different aspects and to provide a list what the various stakeholders in tourism need to consider and how they should react in the case of a political crisis. Gaps in the table that could not be filled by the literature review are filled through suggestions from the authors. Hosts and the local community were usually not integrated in the studied approaches. However, they can be seen as the most affected group by crises in the destination and hence, it is essential to include them in any crisis management approach.

Special attention has to be paid to the role of the media. The general media even has the potential to turn an incident into an actual crisis, because it makes information available and consequently shapes the audience's view on the conflict (Keown-McMullan, 1997, Hass, 2009). However, it is challenging to 
convince the media to actively participate in proactive crisis management, because they do not represent a classical stakeholder with a necessary interest in the situation of the region. Good PR management is essential for the successful collaboration with the media.

The main question remaining with regard to the stakeholder approach is, which entity is in charge of designing and implementing the action plan. For this purpose, the support of federations and associations is recommended, who are specifically aimed at taking control of managing the crisis. Their main task is to make all market participants aware of the correlation between the costs associated with investing in crisis management in the present and the potential future benefits in order to motivate them to actively participate (Joras, et al., 2011).

\section{Conclusion}

It has to be noted that the tourism sector like no other sector relies on the promotion of favorable images, since the tourism product is intangible (Salazar and Graburn, 2014). In general, in crisis management it is important to develop a problem-solving action plan that combines all stakeholders' interests and activities (Raina, Zhao and Gupta, 2010). Active crisis management is aimed at proactively predicting a future crisis, developing and implementing prevention measures and preparing an action plan for accurate steps in case of a crisis (Waller, Lei and Pratten, 2014). However, the equal integration of all stakeholders is mostly difficult, because the government controls all business activities through policies and regulations and therefore plays a more important role than other market participants (Glaesser, 2003).

Nevertheless, private institutions are able to support the effective, conjoint management of a crisis through several activities: In order to avoid the collision of interests between their political interests and the interests of companies and institutions they support, they should focus on cooperating with private institutions that are not dependent on governmental support. To sustain a positive image cooperation and integration of the media is of vital importance. Further, most articles and studies on crisis management in tourism do not mention the role of the local community. In this approach all stakeholders are considered and table 2 shows guidelines, threats and potential for and of possible actions of the different stakeholders. This can be used as an overview for destinations in political crisis situations. However, as every political crisis has its specifics, the table merely provides a supportive overview. Final decisions and requests for action can only be made knowing the specifics of the crisis and the stakeholders in the crisis situation. 
Table 2. Results from Actions and Required Actions of Tourism Stakeholders in Case of Political Crises

\begin{tabular}{|c|c|c|c|c|c|}
\hline \multirow{2}{*}{ Stakeholders (1) } & \multicolumn{2}{|c|}{ Results from Actions } & \multicolumn{3}{|c|}{ Required Actions for Proactive Crisis Management } \\
\hline & Threats & Potential & Pre-Crisis & During Crisis & Post-Crisis \\
\hline Media & $\begin{array}{l}\text { Media can even turn an } \\
\text { incident into a crisis } \\
\text { (2); impacts } \\
\text { immediately visible (3); } \\
\text { Focus only on } \\
\text { circulation figures }\end{array}$ & $\begin{array}{l}\text { Media shapes the } \\
\text { audience's view on the } \\
\text { conflict, makes } \\
\text { information available } \\
\text { (4); potential to spread } \\
\text { a feeling or safety and } \\
\text { security }\end{array}$ & $\begin{array}{l}\text { Provide correct and } \\
\text { consistent information } \\
\text { to the public and } \\
\text { enhancing the image of } \\
\text { the organization or } \\
\text { industry sector faced } \\
\text { with a crisis (5) }\end{array}$ & $\begin{array}{l}\text { Provide correct and } \\
\text { consistent information } \\
\text { to the public and } \\
\text { deliver precise reports } \\
\text { (5) }\end{array}$ & $\begin{array}{l}\text { Provide information and } \\
\text { report about the } \\
\text { improvement of the } \\
\text { situation at the } \\
\text { destination. Support } \\
\text { image rejuvenation }\end{array}$ \\
\hline Public Sector & $\begin{array}{l}\text { Subsidies for } \\
\text { unaffected can be } \\
\text { counter-productive (6); } \\
\text { Tourists expect } \\
\text { protection by } \\
\text { governments and the } \\
\text { industry, but are } \\
\text { responsible for their } \\
\text { own decisions and } \\
\text { actions }(7) \text {; threat of } \\
\text { lobbying and political } \\
\text { restrictions }(14,15)\end{array}$ & $\begin{array}{l}\text { Government measures: } \\
\text { tax incentives, special } \\
\text { import provision to } \\
\text { stimulate foreign } \\
\text { investment, tax relief, } \\
\text { extended credit to } \\
\text { businesses, increased } \\
\text { funding (8) }\end{array}$ & $\begin{array}{l}\text { Include effects on the } \\
\text { tourism industry in } \\
\text { crisis planning. Collect } \\
\text { knowledge from other } \\
\text { crises situations (13, } \\
\text { 19) Enforce crises } \\
\text { preventing measures } \\
\text { (14). Support } \\
\text { foundation of } \\
\text { federations and } \\
\text { associations (15) }\end{array}$ & $\begin{array}{l}\text { Rescue procedures, } \\
\text { emergency } \\
\text { accommodation, food } \\
\text { supplies, medical } \\
\text { services, monitoring } \\
\text { and communication } \\
\text { systems (9); } \\
\text { Cooperation with other } \\
\text { governments and } \\
\text { foreign offices } \\
\text { (standardize travel } \\
\text { information) }\end{array}$ & $\begin{array}{l}\text { Government measures: } \\
\text { tax incentives, special } \\
\text { import provision to } \\
\text { stimulate foreign } \\
\text { investment, tax relief, } \\
\text { extended credit to } \\
\text { businesses, increased } \\
\text { funding (8) }\end{array}$ \\
\hline Private Sector & $\begin{array}{l}\text { Long-term difficulties } \\
\text { lie in restoring the } \\
\text { reputation and image of } \\
\text { the destination (10) }\end{array}$ & $\begin{array}{l}\text { Private sector: develop } \\
\text { new products and } \\
\text { markets (8) High } \\
\text { resilience of the } \\
\text { tourism industry (11) }\end{array}$ & $\begin{array}{l}\text { Warn and or prepare } \\
\text { visitors; offer } \\
\text { alternative destinations; } \\
\text { raise awareness on } \\
\text { potential actions (15, } \\
\text { 18) }\end{array}$ & $\begin{array}{l}\text { Handling visitors; get } \\
\text { away from short-term } \\
\text { profit focus leading to } \\
\text { cost reductions, instead } \\
\text { invest in peace } \\
\text { promotion (15) }\end{array}$ & $\begin{array}{l}\text { Marketing and } \\
\text { promotions are key to } \\
\text { assisting a tourist } \\
\text { destination to recover } \\
\text { after a crisis or disaster } \\
\text { (10) }\end{array}$ \\
\hline
\end{tabular}




\begin{tabular}{|l|l|l|l|l|l|}
\hline Local Community & $\begin{array}{l}\text { Lose welcoming } \\
\text { culture; tourism can } \\
\text { lead to a dissatisfaction } \\
\text { of locals }\end{array}$ & $\begin{array}{l}\text { Behavior could inspire } \\
\text { tourists to visit; Inspire } \\
\text { Voluntourism }\end{array}$ & $\begin{array}{l}\text { Warn tourists on the } \\
\text { developments and give } \\
\text { hints on how to behave }\end{array}$ & $\begin{array}{l}\text { Guide tourists and } \\
\text { inform them about the } \\
\text { situation at the } \\
\text { destination. Give } \\
\text { security advice. }\end{array}$ & $\begin{array}{l}\text { Recognize the } \\
\text { importance of tourism } \\
\text { for economic } \\
\text { development. }\end{array}$ \\
\hline Tourists & $\begin{array}{l}\text { Tourists as target of } \\
\text { terrorist attacks; } \\
\text { Tourists are at greater } \\
\text { risks, because they lack } \\
\text { knowledge on how to } \\
\text { react to danger (12) }\end{array}$ & $\begin{array}{l}\text { High resilience of the } \\
\text { tourism industry means } \\
\text { tourists quickly come } \\
\text { back to destinations } \\
(11)\end{array}$ & $\begin{array}{l}\text { Biggest problem: } \\
\text { change in behavior of } \\
\text { those already planning } \\
\text { a visit (10) }\end{array}$ & $\begin{array}{l}\text { Critically evaluate the } \\
\text { risk associated with } \\
\text { visiting the destination } \\
(16,17)\end{array}$ & $\begin{array}{l}\text { Enhance image } \\
\text { rejuvenation through } \\
\text { proactive word-of-mouth } \\
\text { about the improved } \\
\text { situation at the } \\
\text { destination. }\end{array}$ \\
\hline
\end{tabular}

Sources: 1: Cooper, 2012; 2: Keown-McMullan, 1997; 3: Scott, Laws and Prideaux, 2008; 4: Hass, 2009; 5: Ritchie, 2004; 6: Blake and Sinclair, 2003; 7: Sönmez and Graefe, 1998; 8: Sausmarez, 2007; 9: Xu and Grunewald, 2009; 10: Mair, Ritchie and Walters, 2016; 11: Wintersteiner \& Wohlmuther, 2014; 12: Ritchie, 2008; 13: Raina, Zhao and Gupta, 2010; 14: Glaeser 2003; 15: Joras, et al., 2011; 16: Neumayer, 2004; 17: Reisinger amd Mayondo, 2005; 18: Hayes and Patton, 2001; 19: Ghaderi, Mat Som and Wang, 2014 


\section{Reference List}

Araña, J. E. and León, C. J. (2008). The Impact of Terrorism on Tourism Demand. Annals of Tourism Research. 35 (2), pp. 299-315.

Blake, A. and Sinclair, M. T. (2003). Tourism Crisis Management. US Response to September 11. Annals of Tourism Research. 30 (4), pp. 813-832.

Cooper, C. (2012). Essentials of Tourism. Harlow: Pearson.

Durocher, J. (1994). Recovery Marketing: What to Do After a Natural Disaster. The Cornell Hotel and Restaurant Administration Quarterly. 35 (2), pp. 66-71.

Echtner, C. M. and Ritchie, B. W. (2003). The Meaning and Measurement of Destination Image. The Journal of Tourism Studies. 14 (1), pp. 37-48.

Ghaderi, Z., Mat Som, A. P. and Wang, J. (2014). Organizational Learning in Tourism Crisis Management: An Experience from Malaysia. Journal of Travel \& Tourism Marketing. 31 (5), pp. 627-648.

Glaesser, D. (2003). Crisis Management in the Tourism Industry. Burlington: Butterworth-Heinemann

Gundel, S. (2005). Towards a New Typology of Crises. Journal of Contingencies and Crisis Management. 13 (3), pp. 106-115.

Hass, R. (2009). The Role of Media in Conflict and their Influence on Securitisation. The International Spectator. 44 (4), pp. 77-91.

Hayes, D. and Patton, M. (2001). Proactive Crisis-Management Strategies and the Archaeological Heritage. International Journal of Heritage Studies. 7 (1), pp. 3758.

Hystad, P. W. and Keller, P. C. (2008). Towards a Destination Tourism Disaster Management Framework. Long-term Lessons from a Forest Fire Disaster. Tourism Management. 29, pp. 151-162.

Joras, U., Palme, K., Alluri, R. and Leicher, M. (2011). Tourismus, Frieden und Konflikt: Effekte, Strategien und das Privatwirtschaftliche Engagement in der Friedensförderung. [Tourism, Peace and Conflict: Effects, Strategies and the Commercial Engagement in Peace Promotion. Osnabrück: Deutsche Stiftung Friedensforschung.

Kanlayanasukho, V. (2015). An Analysis of the Tourism Industry's Management Responses to Political Crises in Thailand. In: Ritchie, B.W. and Campiranon, K. (Eds.). Tourism Crisis and Disaster Management in the Asia-Pacific, pp. 116131.

Keown-McMullan, J. (1997). Crisis: When Does a Molehill become a Mountain? Disaster and Prevention Management. 6 (1), pp. 4-10.

Kesić, T. and Pavlić, I. (2011). Tourism Destination Image Formation. The Case of Dubrovnk, Croatia. Trziste/Market. 23 (1), pp. 7-25

Laws, E. and Prideaux, B. (2005). Crisis Management: A Suggested Typology. Journal of Travel \& Tourism Marketing. 19 (2-3), pp. 1-8.

Mair, J., Ritchie, B. W. and Walters, G. (2016). Towards a Resarch Agenda for PostDisaster and Post-Crisis Recovery Strategies for Tourist Destiantions: A Narrative Review. Current Issues in Tourism. 19 (1), pp. 1-26.

Mathes, R., Gärtner, H. and Czaplicki, A. (1993). Krisenkommunikation Teil 1. [Crisis Communication Part 1]. PR Magazin. 11, pp. 31-38.

Neumayer, E. (2004). The Impact of Political Violence on Tourism. Journal of Conflict Resolution. 48 (2), pp. 259-281.

Raina, A., Zhao, J. and Gupta, D. (2010). Tourism Destination Management. Principles and Practices. New Delhi: Kanishka Publishers 
Reisinger, Y. and Mavondo, F. (2005). Travel Anxiety and Intentions to Travel Internationally: Implications of Travel Risk Perception. Journal of Travel Research. 43, pp. 212-225.

Ritchie, B. W. (2004). Chaos, Crisis and Disasters: A Strategic Approach to Crisis Management in the Tourism Industry. Tourism Management. 25, pp. 669-684.

Ritchie, B. W. (2008). Tourism Disaster Planning and Management: From Response and Recovery to Reduction and readiness. Current Issues in Tourism. 11 (4), pp. 315-348.

Salazar, N. and Graburn, N. (2014). Introduction. In Salazar, N. and Graburn, N. (eds.) Tourism Imaginaries. Anthropological Approaches (1-28). New York, Oxford: Berghahn Books.

Sausmarez, N. de (2007a). Crisis Management, Tourism and Sustainability: The Role of Indicators. Journal of Sustainable Tourism. 15 (6), pp. 700-714.

Sausmarez, N. de (2007b). The Potential for Tourism in Post-Crisis Recovery: Lessons from Malaysia's Experience of the Asian Financial Crisis. Asia Pacific Business Review. 13 (2), pp. 277-299.

Sausmarez, N. de (2013). Challenges to Kenyan Tourism Since 2008: Crisis Management from the Kenyan Tour Operator Perspective. Current Issues in Tourism. 16 (7-8), pp. 792- 809.

Scherler, P. (1996). Management der Krisenkommunikation. [Crisis Communication Management]. Basel: Helbig \& Lichtenhahn.

Schlagheck, D. M. (1988). International Terrorism. Lexington MA: Lexington Books.

Scott, N., Laws, E. and Prideaux, B. (2008). Tourism Crises and Marketing Recovery Strategies. Journal of Travel \& Tourism Marketing. 23 (2-4), pp. 1-13.

Sönmez, S. F. and Graefe, A. R. (1998). Influence of Terrorism Risk on Foreign Tourism Decisions. Annals of Tourism Research. 25 (1), pp. 112-144.

Waller, M., Lei, Z. and Pratten, R. (2014). Focusing on Teams in Crisis Management Education: An Integrated and Simulation-Based Approach. Academy of Management Learning \& Education. 13 (2), pp. 208-221.

Wintersteiner, W. and Wohlmuther, C. (2014). Peace Sensitive Tourism. How Tourism Can Contribute to Peace. In: Wohlmuther, C. and Wintersteiner, W. (Eds.). International Handbook of Tourism and Peace, pp. 31-61.

$\mathrm{Xu}$, J. and Grunewald, A. (2009). What Have We Learned? A Critical Review of Tourism Disaster Management. Journal of China Tourism Research. 5 (1), pp. 102-130. 
